\title{
Superior sagittal sinus thrombosis in a case of Mixed Connective Tissue Disease
}

\author{
Preet Mukesh Shah, ${ }^{1}$ Vijay Waman Dhakre, ${ }^{2,3}$ Anand Bhabhor, ${ }^{1}$ Abhijeet Prasad ${ }^{4}$
}

'Department of Critical Care Jaslok Hospital and Research Centre, Mumbai, Maharashtra, India

${ }^{2}$ Global Institute of Liver Diseases, HPB Surgery and Transplantation, Mumbai, Maharashtra, India ${ }^{3}$ Department of Liver Diseases, HPB Surgery and Transplantation, Mumbai, Maharashtra, India ${ }^{4}$ Department of General Medicine, Jaslok Hospital and Research Centre, Mumbai, Maharashtra, India

Correspondence to Dr. Preet Mukesh Shah, drpreetshah@gmail.com

Presented as a poster at APICON 2017

Accepted 22 April 2018

\section{DESCRIPTION}

A 21-year-old man presented with fever and leftsided chest pain since 4 days. His medical and family history were insignificant, with no history of rheumatological disease.

On examination, he was tachypnoeic (with a respiratory rate of $28 / \mathrm{min}$ ), tachycardic (with a pulse of $120 / \mathrm{min}$ ), febrile (with a temperature of $101^{\circ} \mathrm{F}$ ) and had a stony dull note on percussing the left side of the chest, with decreased vesicular breath sounds on auscultation on the same side.

X-ray of the chest revealed bilateral pleural effusion (figure 1) which was aspirated and was found to be exudative in character, and there were 2100 cells, of which $65 \%$ were neutrophils; pleural fluid Adenosine Deaminase, Gene Xpert, culture, staining and cytology were negative. Blood culture was negative, and his complete blood count showed leucocytosis. Erythrocyte sedimentation rate was $65 \mathrm{~mm} /$ hour, Antinuclear Antibodies(ANA) was 4+ (speckled pattern) and C3, C4 levels were low, anti-U1RNP antibody was positive, anti-Sm antibody was positive, anti-Ro antibody was positive, anti-La antibody was positive; whereas anti-Scl70 antibodies, anti-Jo-1 antibodies, anti-CCP(cyclic citrullinated peptide) antibodies, p-ANCA (Antineutrophil cytoplasmic antibodies) and c-ANCA(Antineutrophil cytoplasmic antibodies) were all negative. CT of the chest and abdomen showed enlargement of cervical, axillary, mediastinal, abdominal and inguinal lymph nodes. Lymph node biopsy was done, and the histopathological analysis showed reactive lymph nodes with no features of necrosis/granulomas, and it was not suggestive of malignancy/tuberculosis. In view of the serological

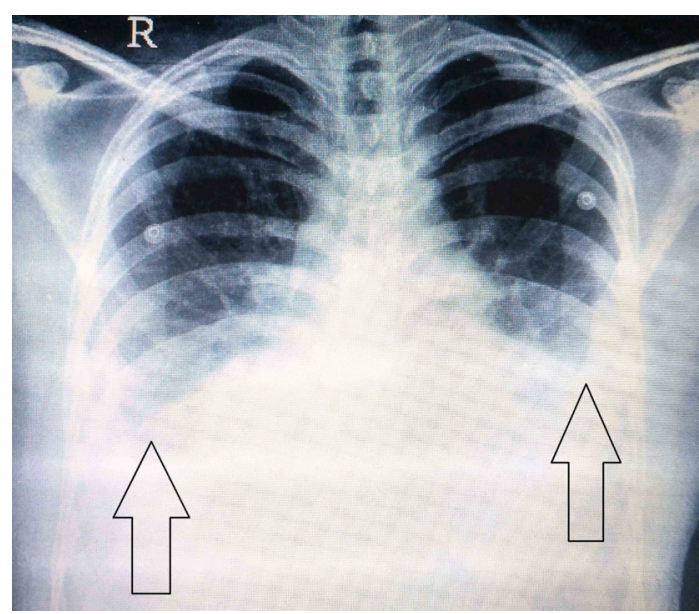

Figure 1 X-ray of the chest showing bilateral pleural effusion (black arrows).

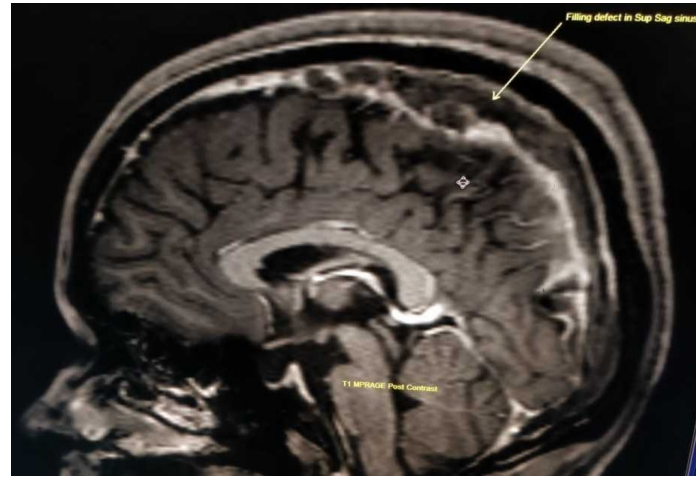

Figure 2 MRI brain (T1 sequence postcontrastsagittal view) showing filling defect in the superior sagittal sinus (yellow arrow), suggestive of superior sagittal sinus thrombosis.

features, a diagnosis of mixed connective tissue disease (MCTD) was made. He was started on prednisolone, after which his fever and symptoms improved.

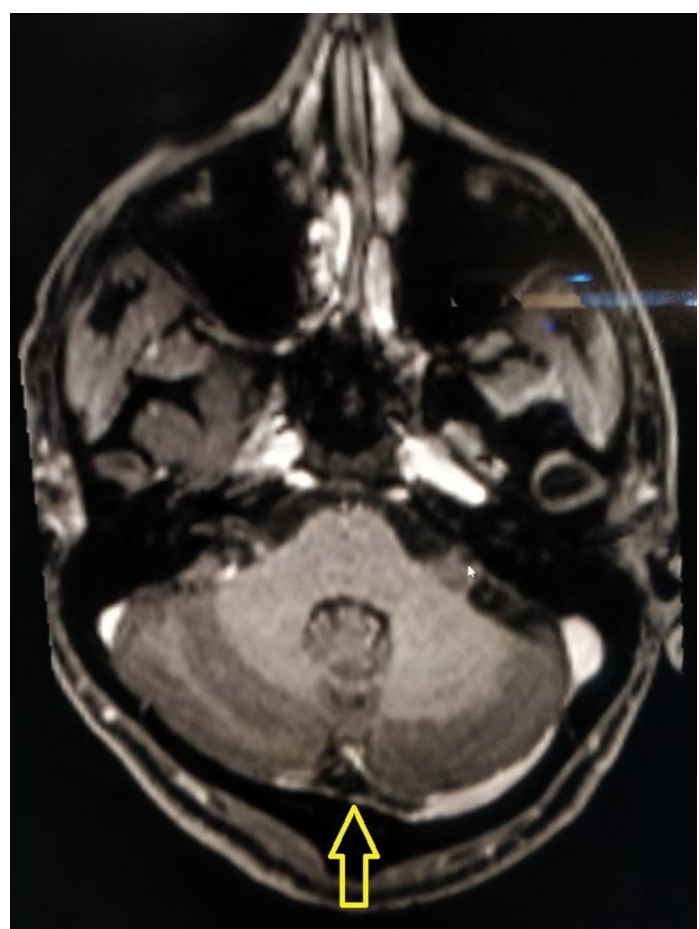

Figure 3 MRI brain (T1 sequence postcontrastcoronal view) showing normal opacification of the left transverse sinus whereas sagittal sinus (yellow arrow) is non-opacified, suggestive of superior sagittal sinus thrombosis. 
A month later, he presented with headache which was continuous in nature, dull aching, bifrontal in location, without phonophobia or any postural variation, associated with multiple episodes of projectile vomiting. Examination showed a positive Kernig's sign, bilateral brisk deep tendon reflexes and plantar responses were extensor bilaterally, with normal funduscopy. His MRI brain was suggestive of superior sagittal sinus thrombosis (figures 2 and 3). His thrombophilia profile was negative. It was concluded that his MCTD contributed to the development of superior sagittal sinus thrombosis. Antioedema measures were started, and then he was started on low-molecular weight heparin and warfarin. His steroid supplementation continued. Gradually, the patient's symptoms resolved, and he was advised to continue the steroid (which was to be slowly tapered) and the warfarin. The patient came for follow-up after 1 month. He was asymptomatic with no headache or any other complaints. There was no neurological deficit on examination. He was advised to continue warfarin and prednisolone lifelong.

\section{Learning points}

- Cerebral venous sinus thrombosis is a very rare neurological manifestation of mixed connective tissue disease.

- Headache in the background of mixed connective tissue disease can be due to superior sagittal sinus thrombosis and should not be ignored as a vague symptom. It merits further evaluation.
MCTD is an overlap syndrome that includes features of systemic lupus erythematosus, systemic sclerosis and polymyositis and is associated with the presence of anti-U1 RNP antibodies. ${ }^{1}$ Incidence of pleural effusion in MCTD is $50 \%{ }^{1}$ which is usually exudative, and $\mathrm{PMN}$ (polymorphonuclear leukocytes) cells predominate. ${ }^{2}$ The most common neurological feature of MCTD is trigeminal neuropathy, with cerebral venous sinus thrombosis not being described in literature. ${ }^{3}$ We believe our patient is the first case of MCTD in whom cerebral venous sinus thrombosis has occurred.

Acknowledgements Dr. Aman Snehil (Department of Radiology, Jaslok Hospital and Research Centre, Mumbai) assisted in selecting the appropriate MRI images.

Contributors PMS wrote up the case details. VWD and AB assisted in the discussion of the case. AP acquired the clinical images.

Funding This research received no specific grant from any funding agency in the public, commercial or not-for-profit sectors.

Competing interests None declared.

Patient consent Obtained.

Provenance and peer review Not commissioned; externally peer reviewed.

(c) BMJ Publishing Group Ltd (unless otherwise stated in the text of the article) 2018. All rights reserved. No commercial use is permitted unless otherwise expressly granted.

\section{REFERENCES}

1 Prakash UB. Respiratory complications in mixed connective tissue disease. Clin Chest Med 1998;19:733-46.

2 Joseph J, Sahn SA. Connective tissue diseases and the pleura. Chest 1993;104:262-70

3 Bennett R. Clinical manifestations of mixed connective tissue disease. Curtis M, ed. Waltham, Mass: UpToDate, 2018. www.uptodate.com/contents/clinical-manifestationsof-mixed-connective-tissue-disease. (accessed 9 Mar 2018).

Copyright 2018 BMJ Publishing Group. All rights reserved. For permission to reuse any of this content visit

http://group.bmj.com/group/rights-licensing/permissions.

BMJ Case Report Fellows may re-use this article for personal use and teaching without any further permission.

Become a Fellow of BMJ Case Reports today and you can:

- Submit as many cases as you like

- Enjoy fast sympathetic peer review and rapid publication of accepted articles

- Access all the published articles

Re-use any of the published material for personal use and teaching without further permission

For information on Institutional Fellowships contact consortiasales@bmjgroup.com

Visit casereports.bmj.com for more articles like this and to become a Fellow 